\title{
Evaluation of Acacia Mangium in Structural Size at Green Condition
}

\author{
Gaddafi Ismaili, Badorul Hisham Abu Bakar and Khairul Khuzaimah Abdul Rahim
}

\begin{abstract}
Acacia mangium is one of the most popular choices in the reforestation and rehabilitation of abandoned shifting cultivation areas dated back to the 70's. This paper looks into the evaluation of mechanical strength and physical properties in structural size at green condition for Acacia mangium. The mechanical strength properties tests were referred to the modulus of rupture, modulus of elasticity and tensile strength. Meanwhile, physical properties determination referred to basic density and moisture content. At green condition, Acacia mangium had been identified under the strength group SG6. It was found that strength value of modulus of rupture was higher than the tensile strength value with $44 \%$ stronger in bending compared to in tension. At the structural size, the mean value for moisture content and basic density at green condition were reported with $73.03 \%$ and $0.54 \mathrm{~g} / \mathrm{cm}^{3}$ respectively.
\end{abstract}

Keywords: Modulus of rupture, modulus of elasticity, tensile strength, basic density and moisture content

\section{INTRODUCTION}

A cacia mangium (Fabaceae: Mimosoideae) is a perennial tree native to Australia and Asia. Common names for it include Black Wattle, Hickory Wattle and Mangium. The species was selected for this study as a result of some factors. One of the main factors is due to its fast growing characteristics. Besides that, it is also one of the major plantation species in Malaysia. Successful plantations of this species were reported from Sabah [4]. In Sarawak, this species is most widely used in the reforestation and rehabilitation of abandoned shifting cultivation areas [12]. This is because the species is very adaptable to a wide range of soil types that it even thrives on degraded sites where shifting cultivation had been practiced, on hill slopes overgrown with weeds like Imperata and Eupatorium species, and in areas subjected to seasonal flooding or areas leveled by tractors [21].

Structural usage of the timber is definitely one of the potential areas to explore [4]. A detailed knowledge of the growth and structure of wood is essential to the design of efficient timber structures. Nevertheless, an understanding of its characteristics may help engineer and designer to appreciate the behavior of wood as a constructional material [20]. Consequently, the purpose of this study is to evaluate Acacia mangium in structural size at green condition associated to the mechanical strength characteristic.

\section{MATERIALS AND METHODS}

Materials and sampling methods

A total of 29 Acacia mangium trees were collected from Sabal Reforestation Plot. The age of the trees was about 23 years old. From these trees, a total of 323 samples were recovered. From those 323 samples, only the results from 50 samples at green condition were selected randomly and presented. The remaining samples are still in the process of air-drying and will be utilized for further studies.

Gaddafi Ismaili was with Reliability Integrity Engineering Department, PETRONAS Carigali Sdn. Bhd., Sarawak Operations, Jalan Sekolah, 98008, Lutong, Miri, Sarawak. He is now with the Faculty of Engineering, Universiti Malaysia Sarawak, Kota Samarahan, 94300 Kota Samarahan, Sarawak, Malaysia (phone: +60 8258 3432; fax: +60 82 583409; e-mail: igaddafi@ feng.unimas.my).

Assoc. Prof Dr. Badorul Hisham Abu Bakar is with the School of Civil Engineering, Universiti Sains Malaysia, Engineering Campus, 14300, Nibong Tebal, Seberang Perai, Pulau Pinang, Malaysia (phone: +604 5996298; fax: +604 5941009; e-mail: cebad@eng.usm.my).

Khairul Khuzaimah Abdul Rahim, was with Applied Forest Science and Industry Development Division, Sarawak Forestry Corporation Sdn. Bhd., Lot 218, KCLD Jalan Tapang, Kota Sentosa, 93250 Kuching, Sarawak Malaysia. She is now with the Infrastructure Planning and Development, Protected Areas and Biodiversity Conservation Divison, Sarawak Forestry Corporation Sdn Bhd, Lot 218, KCLD Jalan Tapang, Kota Sentosa, 93250 Kuching, Sarawak Malaysia (phone: +60 8262 9667; fax: +60 8262 9450; e-mail: khairulkr@ sarawakforestry.com) 
Selection of trees carried out for the samples were done at random basis. Then, the felled trees were sawn to logs form with length about $2.1 \mathrm{~m}$. Some allowance was given for the planning and air-drying process. Subsequently, the logs were marked and then sawn to $127 \times 127 \mathrm{~mm}$ flitches. The logs were firstly sawn at two opposite's sides (Figure 1) to relieve the stress from the logs. Consequently, this was to avoid the flitches from bending outward when they were sawn through the middle of the logs.

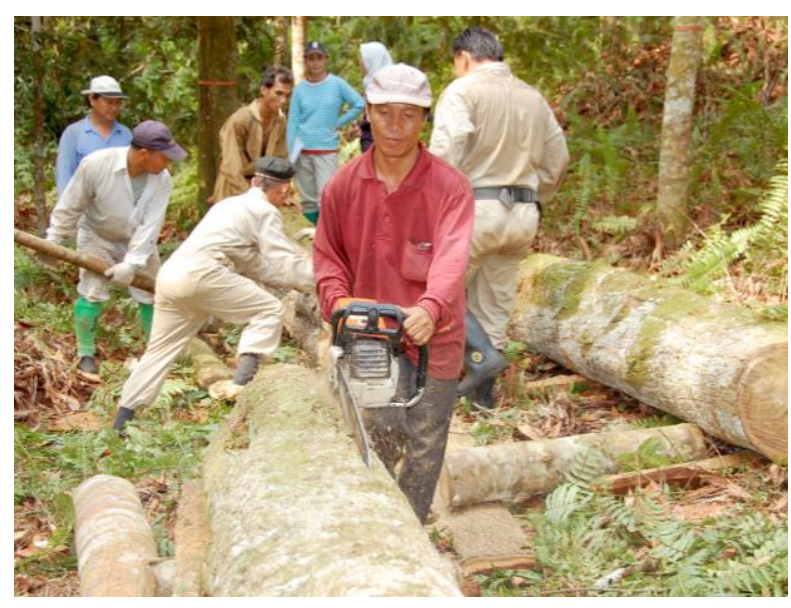

Figure 1: Sawing of $\log$ s to flitches forms.

Next, the flitches undergo the machining process. During this process, flitches are ripped to sample pieces. The ripped samples were also given some allowance for the planning and air-drying process. From these green samples, 50 samples were taken to undergo the planning process to a target size of $50 \times 100 \times 2000 \mathrm{~mm}$. Balances of samples are stacked properly for air-drying process (Figure 2).

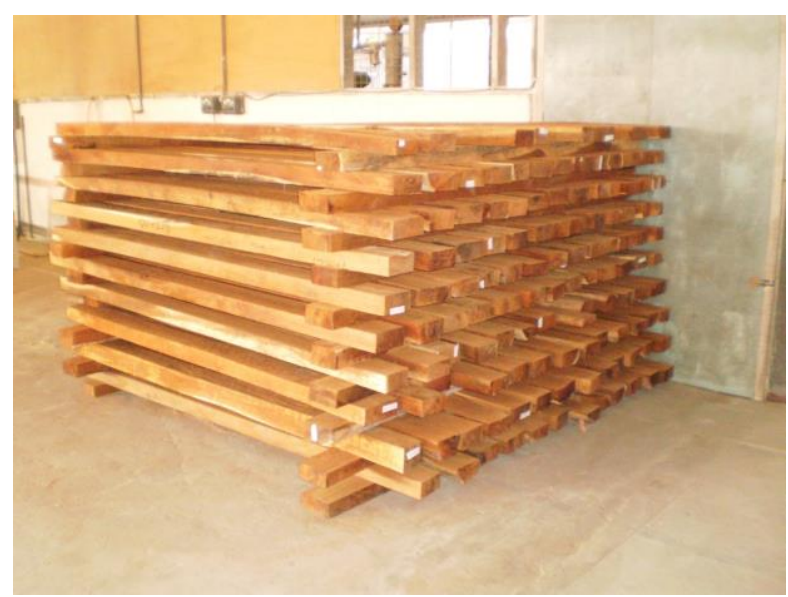

Figure 2: Samples undergoing air-drying process.

Testing methods

\section{Mechanical Strength properties}

There were two types of strength test conducted namely structural bending test and structural tensile test. Testing was done in accordance to the British Standard BS 5820:1979. The testing room condition was maintained at room temperature of $23 \pm$ $3^{\circ} \mathrm{C}$. Bending test was conducted using an Instron Universal Testing Machine, which has a loading capacity of $200 \mathrm{kN}$ (Figure 4) with a loading rate of $8 \mathrm{~mm} / \mathrm{min}$. The support span for this test was $1800 \mathrm{~mm}$, and its loading span was $600 \mathrm{~mm}$. Samples were places on rollers, which are at a free support condition. The values of modulus of rupture and modulus of elasticity were electronically calculated by the machine. 


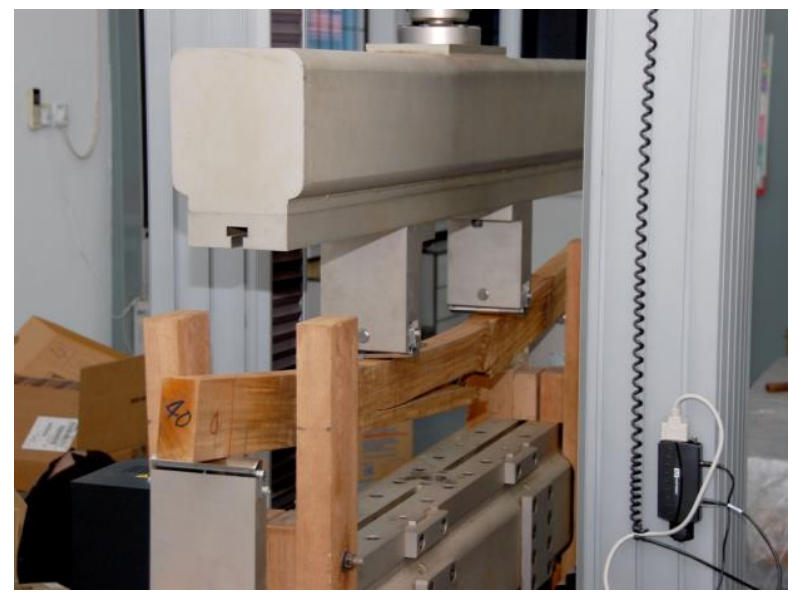

Figure 3: Structural bending test.

On the other hand, the tensile test was conducted using Maekawa Horizontal Tensile Machine with a capacity of $1000 \mathrm{kN}$ (Figure 4). The test samples were loaded using gripping devices, which will permit as far as possible the application of uniform tension without inducing bending. Distance between both grips was $1000 \mathrm{~mm}$, and the applied load was at a continuous speed rate of $6 \mathrm{~mm} / \mathrm{min}$. The formula (1) to obtain the values of tensile strength is shown below:

TS $=\frac{P_{\max }}{b h}$
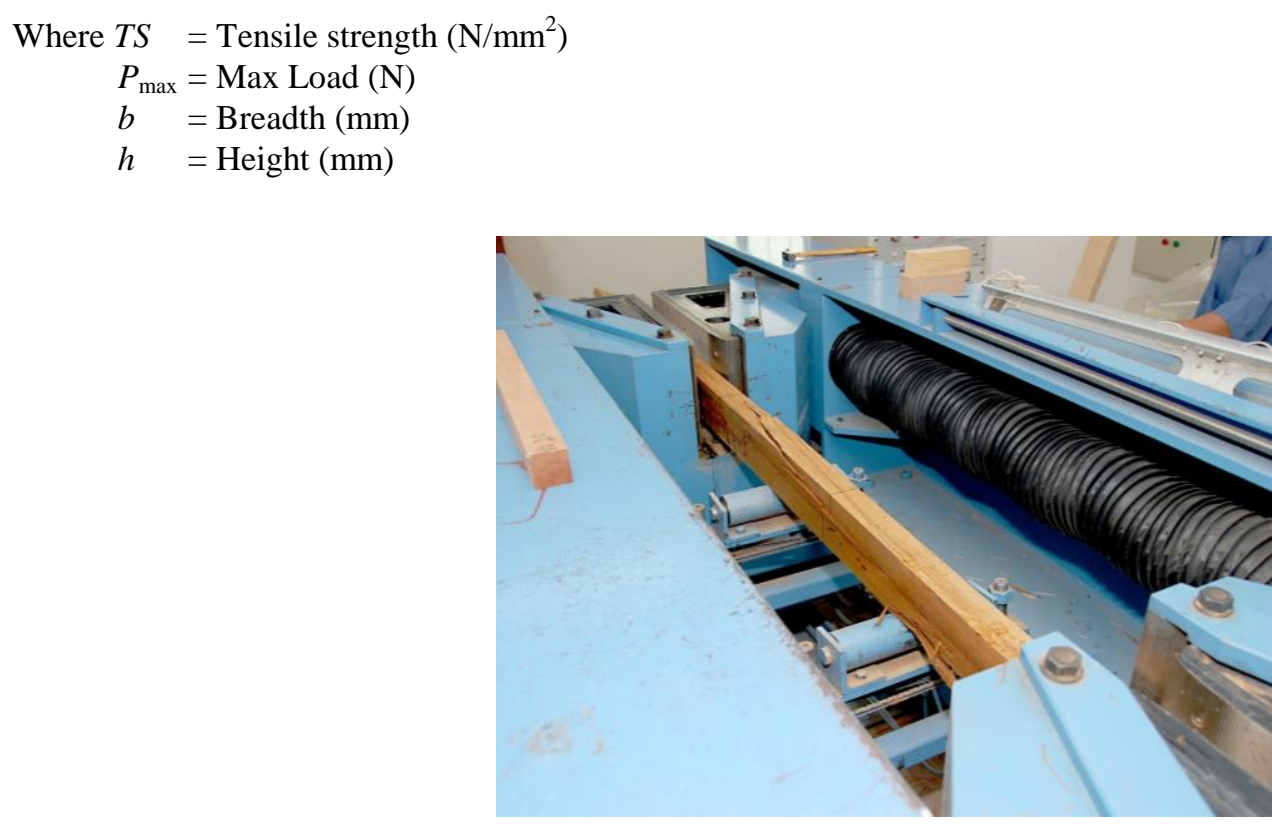

Figure 4: Structural tensile test.

\section{Physical properties}

Moisture content determination

Moisture content determination was conducted directly after the processing was completed. This was to ensure that the moisture content inside the samples was properly conserved. At that point, the initial weights were taken. Then, samples were 
placed in the oven at $103 \pm 2^{\circ} \mathrm{C}$ until the constant weight was achieved. Afterward, the oven-dried weights were taken. Therefore, the moisture content values were determined by using the formula (2) below:

Moisturecontent, $(\%)=\frac{W_{i}-W_{o}}{W_{o}} \times 100$

Where $W_{i}=$ Initial weight $(\mathrm{g})$

$W_{o}=$ Oven-dry weight $(\mathrm{g})$

Basic density determination

Basic density determination test were conducted using the same samples used for moisture content determination test Thus, the dimensions of the green samples were taken before they were placed into the oven to find out the green volumes. The values of the oven-dried were also needed to complete the formula used to determine the basic density as follows:

$B D=\frac{W_{o}}{V_{g}}$

Where $B D=$ Basic Density $\left(\mathrm{g} / \mathrm{cm}^{3}\right)$

$W_{o}=$ Oven-dry weight $(\mathrm{g})$

$V_{g}=$ Volume at green condition $\left(\mathrm{cm}^{3}\right)$

\section{RESULTS AND DISCUSSION}

Materials and sampling methods

The results of modulus of rupture, modulus of elasticity and tensile strength of structural size samples is shown in Table 1 . The mean values of modulus of rupture, modulus of elasticity and tensile strength are $60.95 \mathrm{~N} / \mathrm{mm}^{2}, 13262 \mathrm{~N} / \mathrm{mm}^{2}$ and 42.32 $\mathrm{N} / \mathrm{mm}^{2}$ with its coefficient of variation $16.16 \%, 10.89 \%$ and $22.67 \%$ respectively.

Table 1: Summary of results for Acacia mangium at green condition.

\begin{tabular}{|c|c|c|c|c|c|}
\hline \multirow{2}{*}{$\begin{array}{c}\text { Statistical } \\
\text { Analysis }\end{array}$} & MOR & MOE & Tensile Strength & $\begin{array}{c}\text { Basic } \\
\text { Density }\end{array}$ & $\begin{array}{c}\text { Moisture } \\
\text { Content }\end{array}$ \\
\cline { 2 - 6 } & $\mathrm{N} / \mathrm{mm}^{2}$ & $\mathrm{~N} / \mathrm{mm}^{2}$ & $\mathrm{~N} / \mathrm{mm}^{2}$ & $\mathrm{~g} / \mathrm{cm}^{3}$ & $\%$ \\
\hline Mean & 60.95 & 13262 & 42.32 & 0.54 & 73.03 \\
\hline STDEV & 9.85 & 1444 & 9.60 & 0.05 & 11.93 \\
\hline CV\% & 16.16 & 10.89 & 22.67 & 8.83 & 16.33 \\
\hline $\mathrm{n}$ & \multicolumn{2}{|c|}{25} & 25 & \multicolumn{2}{c|}{50} \\
\hline
\end{tabular}

Note:

MOR $=$ Modulus of rupture

MOE = Modulus of elasticity

Mean $=$ Mean values

STDEV = Standard deviation

$\mathrm{CV}=$ Coefficient of variation

$\mathrm{n}=$ Number of specimens

The coefficient of variation is quit high for every result parameter mentioned with the exceptions on the modulus of rupture $10.89 \%$. One of the main reasons is probably due to lacking in the number of specimens. Basically, if a higher number of specimens were used, the coefficient of variation would definitely be lower. Besides that, the occurrence of defects such as knots, sloping grain and inherent properties might reduce the strength values of timber. Based on the strength of green samples, the timber can be group in the SG 6 [6] which is in the same grouping with species such as Bindang (Agathis 
spp.), Jongkong (Dactylocladus stenostachys), Yellow Meranti (Shorea spp.), Mersawa (Anisoptera spp.), Durian (Durio spp.) etc. Therefore, the timber species may be recommended for structural applications.

Physical properties

Fiber-saturation point of most timber species is between the ranges of 25 to $30 \%$. Therefore, timber samples would be considered to be in green condition when its moisture content value is above that range. For that reason, all specimens were considered to be in green condition with mean moisture content of $73.03 \%$ which ranges between $53.08 \%$ and $117 \%$.

There was a marked increase in strength of timber species tested from green to air-dried condition [1]. The increment of strength with reduction in moisture is because of shortening and consequently, strengthening of hydrogen bonds linking together the microfibrils [13], [9]. Nevertheless, the effect of moisture is less significant on some mechanical properties of timber [18], [19], [15]. Thus, samples of air-dried condition of the timber will be tested.

Wood density provides a simple measurement of the total amount of solid-wood substances in a piece of wood [17]. The mean value of basic density was $0.54 \mathrm{~g} / \mathrm{cm}^{3}$ with the coefficient of percentage of $8.83 \%$. Therefore, Acacia mangium is classified under Light Hardwood [7].

From the results, the coefficient of variation of most parameters is quit high. The occurrences of defects mainly big size knots promote to this matter. It is well known that the strength and stiffness of wood members containing knots is reduced due to the disruption of the grain in the region of the knot [22]. Knots influence the strength properties of a piece of wood to a varying degree depending on the size, position and type [11]. However, there is no difference in the effects between live and dead knot as far as stress grading of timber is concerned [9].

The location of knots affects the bending strength more because the distribution stress varies along the depth of a beam [10], [14]. Based on timber failures, out of the total number tested for structural bending, roughly $90 \%$ of the timber samples failure started from compression and finally ended with tension failures (Figure 5). The failures pattern was similar to the small clear specimens. A knot that is located close to the axis will have less effect on strength than the one located close to the edge. Referring to Figure 6, this is true especially for the edge subjected to tensile stresses since the effect is more in tension rather than in compression [2], [10].

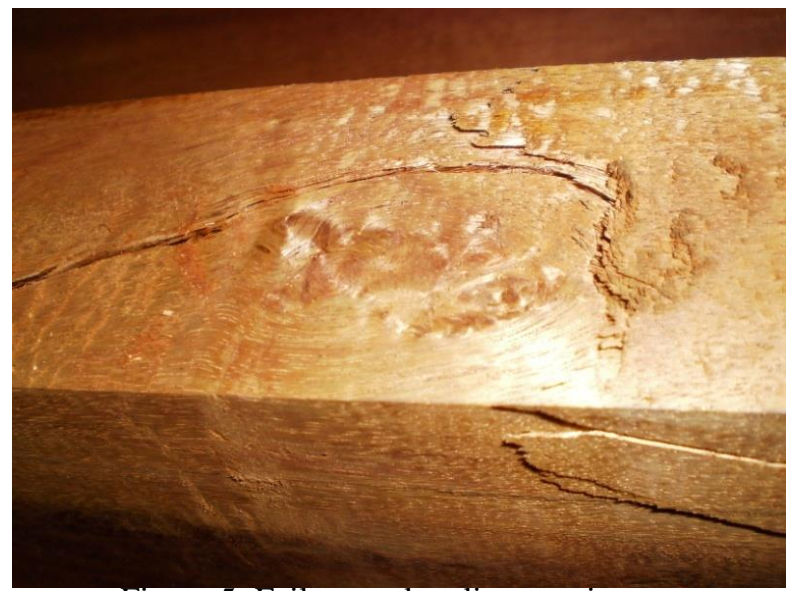

Figure 5: Failure on bending specimens.

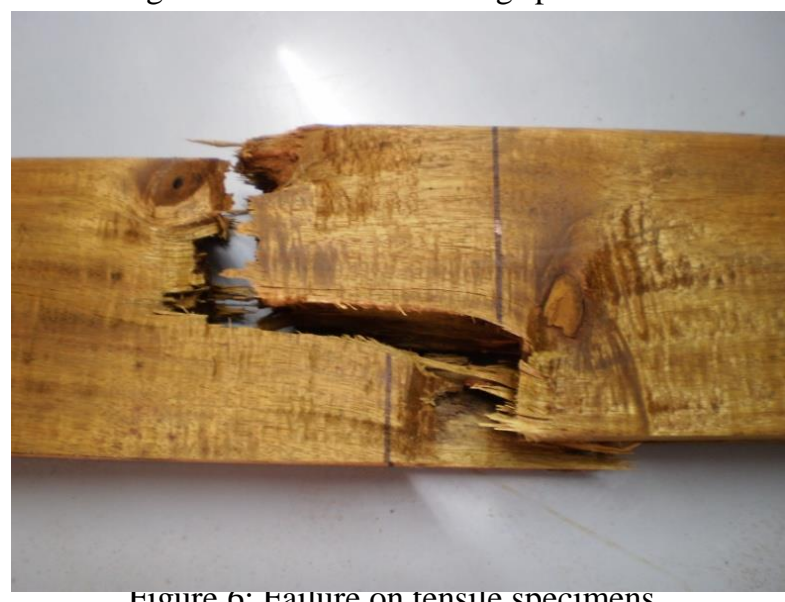

Figure 0: Fallure on tensile specimens. 


\section{CONCLUSION}

The results obtained from structural size very much different with small clear specimen. This was due to the homogenous behavior in timber that been tested in structural size compared to small clear specimen or defect free sample. The differences can be identified where the small clear specimen recorded with modulus of rupture mean value $86.4 \mathrm{~N} / \mathrm{mm}^{2}$ [3] which was $29.46 \%$ higher than the mean value obtained from structural size with $60.95 \mathrm{~N} / \mathrm{mm}^{2}$. For modulus of elasticity, the small clear result obtained with $10900 \mathrm{~N} / \mathrm{mm}^{2}$ [3] which was $17.81 \%$ lower than the result acquired from structural size with $13262 \mathrm{~N} / \mathrm{mm}^{2}$.

\section{ACKNOWLEDGMENT}

The authors would like to gratefully acknowledge everyone involve in this project, especially to Research Manager, Dr. Alik Duju. Thank you all for your guidance and support.

\section{REFERENCES}

[1] Alik, D. \& Kuroda, N.,1996. The Relationship Between Basic Density and Mechanical Strength Properties of Some Sarawak Timbers. Proceedings of TRTTC/STA Forest Products Seminar 96. Kuching, Sarawak. March 11-13, p.117-127.

[2] Alik, D. \& Nakai, T., 1997a. Preliminary Study for Stuructural Grading Based on Full Size Bending Test of Resak, Durian and Keruing Utap of Sarawak. Proceedings of the International Tropical Wood Conference, Kuala Lumpur. June 17-20, p.252-260.

[3] Alik Duju (1999), Strength Properties of Acacia mangium Grown in Sarawak. TRTTC/STA, Forest Products Seminar, 12-14 October 1999, Kuching, Sarawak, Malaysia. 160pp.

[4] Alik, D., \& Nakai, T. 2000. Mechanical Properties of Acacia mangium Planted in Sarawak, Malaysia. Paper Presented in the XXI IUFRO World Congress 2000. Kuala Lumpur August 7-12.

[5] Anon., 1979. British Standard 5820:1979. Methods of Test for Determination of Certain Physical and Mechanical Properties of Timber in Structural Sizes. British Standard Institution.

[6] Anon,. Malaysian Standard-Code of Practice for Structural Use of Timber: MS 544: Part 2:2001 . Department Of Standards Malaysia.

[7] Anon., 1984. The Malaysian Grading Rules for Sawn Hardwood Timber. Ministry of Primary Industries.

[8] Anon., 1995. Timber Engineering Step 1. Basic of Design, Material Properties, Structural Components and Joints. Centrum Hout. Netherlands. C19/9.

[9] Anon., 1995. Wood Handbook. Forest Products Laboratory. U.S Department of Agriculture Handbook No.72. U.S Government Printing Office. Washington.

[10] Anon., 1999a. Wood Handbook. Wood as an Engineering Material. Forest Products Laboratory. Report FPL-GTR-113. USA, Washington. p.19-14.

[11] Chu, Y.P.,Ho, K.S., Mohd, S. M. \& Abdul, R. A. M., 1997. Timber Design Handbook. Malayan Forest Records No.42. Forest Research Institute Malaysia. 288 pp.

[12] Christine, J.H. 1988. The Ecology of an Acacia mangium Plantation Established after Shifting Cultivation in Niah Forest Reserve. Forest research report. Forest Department Sarawak.

[13] Desch, H. E. \& Dinwoodie, J.M., 1981. Timber Its Structure, Properties and Utilisation. $6^{\text {th }}$ Edition. Macmillan Press Limited. 410 p.

[14] Gurfinkel, G., 1973. Wood Engineering. Southern Forest Products Association. Upon Printing Co. USA.

[15] Hoffmeyer, P., 1978. Moisture Content Strength Relationship for Spruce Lumber Subjected to Bending, Compression and Tension along the Grain Proceedings of IUFRO Timber Engineering Conference, Vancouver, B.C. Canada.

[16] http://www.worldagroforestrycentre.org/sites/TreeDBS/aft/speciesPrinterFriendly.asp?Id=69 . Visited on November 19, 2008.

[17] Jozsa, L.A. \& Middleton, G. R., 1994. A Discussion of Wood Quality Attributes and their Practical Implication. Forintek Canada Corp. Natural Resources Canada and British Columbia Ministry of Forests.

[18] Madsen, B., 1975. Moisture Content Strength Relationship for Lumber Subjected to Bending. Structural Research Series Report No.11. Department of Structural Engineering. U.B.C Vancouver, Canada.

[19] Madsen, B., Janzen, W. \& Zwaagstra, T., 1980. Moisture Effects in Lumber. Structural Research Series Report No. 27. Department of Structural Engineering. U.B.C Vancouver, Canada.

[20] Pearson, R.G., Kloot, N. H. \& Boyd, J. D. 1962. Timber Engineering Design Handbook. Commonwealth Scientific and Industrial Research Organization, Australia. Jacaranda Press. 264 p.

[21] Tham, C.K. 1978. Introduction to a Plantation Species - Acacia Mangium Willd. Proceedings of the $6^{\text {th }}$ Malaysian Forestry Conference, 1976, Kuching, Sarawak. Vol.2:153-158.

[22] Zink, A.G. 1993. Stress Analysis of Wood with Knots. Systems Approach to Wood Structures. Proceedings from the Wood Engineering Division Sessions at the 1993 Annual Meeting of the Forest Products Society. June 20-23. 